\title{
Child Workers
}

\section{In Hazardous Industries in Pakistan*}

Akmal Hussain

\begin{abstract}
This paper is the first systematic attempt at understanding the nature and extent of hazards faced by child workers in the construction and related industries, which perhaps are not only growing more rapidly but have far greater hazards than any other set of occupations in which children are employed.
\end{abstract}

This study is based on a field survey of 400 child workers in 200 small-scale establishments in Lahore. Section I places the study in the overall perspective of child work in Pakistan. An estimate of the total number of child workers in the country is made, the latest legislation on child labour discussed and the working conditions of children in the major occupations are analysed. Section II is devoted to a discussion of the specific working conditions of children in the construction and related industries, based on gleaning the available secondary sources. In Section III the evidence of our own field survey which is focussed on the issue of hazards faced by working children in the construction and related industries is presented. The major hazards in addition to sexual abuse and employer violence against child workers are examined on the basis of quantitative data. The numbers of casualties resulting from each type of hazard and in each type of industry are indicated. An attempt is made to construct a standardised index of hazards so as to assess the degree to which a particular hazard is 1ethal. Similarly, a standardised "Danger Index" is constructed to enable us to assess the degree to which a particular industry is dangerous with respect to work safety risk and accidents. Section III also analyses the survey data on wages and age groups of child workers, the income of their families, their family status and employer education.

The paper ends with Section IV with a discussion on a three fold policy response and action that needs to be urgently undertaken in view of the survey findings.

\footnotetext{
${ }^{*}$ An earlier version of this paper was submitted to the International Labour Organization Geneva, Switzerland on October 1, 1992, and included as an annexure in my book titled: Poverty Alleviation in Pakistan.
} 


\section{Child Workers in National Perspective}

\section{The Question of Numbers}

A range of studies has provided quite different estimates of the number of working children in Pakistan. The UNICEF 1992 Study $^{1}$ puts forward the figure of 2.01 million working children, while acknowledging that it may be underestimated. This figure from the 1981 Population Census reports 2.01 million children between the ages of 10 to 14 years as working. Similarly, the earlier UNICEF (1992) Study ${ }^{2}$ estimates that 21.5 per cent of the child population in the 10 to 14 age group were working which means 2.7 million working children (Given the 1981 Census figure of 11.1 million for child population in the $10-14$ age group). Both these estimates are unreliable for two reasons:

(a) The Census figure for working children is likely to be incorrect, since the respondents are male heads of household who are likely to conceal the number of their children at work for fear of legal action against them.

(b) The figure for working children is drawn from the age group 10 14 , while a significant proportion of working children may be in the age group 5 to $<10$.

A far better estimate is the one made by the Planning Commission. According to this estimate, there are 8 million working children in Pakistan. ${ }^{3}$ While this figure may have to some overcome extent the downward reporting bias for working children that is inherent to the Census methodology, yet it is still an underestimate since it does not include working children in the age group 5 to $<10$. I have attempted to cautiously improve the Planning Commission estimate to overcome this bias, and the figure for working children in the age group 5 to $<15$ totals 8.65 million in the year $1990 .^{4}$

${ }^{1}$ UNICEF/Government of Pakistan: "Situation Analysis of Children and Women in Pakistan", 1992.

${ }^{2}$ UNICEF (Punjab Programme Office): "Preliminary. Study and Survey on Health Hazards and Working Children", December 1992.

3 "National Programme of Action for the Goals for Children and Development in the 1990's", Government of Pakistan, Planning Commission, (Not dated).

${ }^{4}$ My estimate uses the Population Census figure for children in the age group 5 to 9 , then estimates the number of children in this age group below the poverty line on the basis of Ercelawn's national average figure of 40 percent (1990). Then number of working children in this age group is estimated by applying the Planning Commission ratio of 12 


\section{The New Legislation on Child Work and Employment}

After signing the 1990 International Convention on the Rights of the Child, the government of Pakistan repealed the obsolete Employment of Children Act 1938, and enacted a new law called the Employment of Children Act 1991. This law has four parts.

Part I of the 1991 Act defines children as persons below the age of 14 (which is at variance with the Convention which regards all persons below 18 as children).

Part II of the 1991 Act prohibits the employment of children in any occupation or process related to transport or ancillary operations, the manufacture of matches, crackers and fireworks, biris (which consists of tobacco rolled into a leaf), carpets, cement, cloth dyeing and weaving, mica, soap, wool cleaning, building and construction, slate pencils (making and packing), agate products and toxic substances such as pesticides, chromium, benzene asbestos, etc. However, the catch is that the above prohibition exempts cases where any of these hazardous occupations are carried on by a person with the help of his family members.

Part III of the 1991 Act permits child employment in occupations other than those mentioned above and attempts to regulate the conditions of work of children. Thus they are prohibited from working between 7 p.m. and 8 a.m.; the maximum working hours permitted are seven, with a break of at least one hour after three hours of continuous work. No overtime is allowed, nor is a child allowed to take up two jobs simultaneously. A working child is entitled to at least one weekly holiday. All establishments employing children are required by this law to notify the government about the nature of work and working conditions. These establishments are expected to conform to health and safety standards prescribed by the government and to ensure clean and hazard-free working conditions for children.

Part IV of the 1991 Act prescribes penalties for breaches of any of the provisions of the Act by employers. These include imprisonment for a period extending to one year and a fine of upto twenty thousand Rupees. While these penalties are more severe than those provided under the earlier child labour legislation, yet they are mild when we consider the impact on the health, safety and psyche of the child when the provisions are violated.

percent to the category of poor children in this age group. The working children in this age group are then added on to the Planning Commission figure of working children in the age group 10 to 14 . 
Moreover, they are not enforceable against family members and unregistered establishments.

Manufacturing units employing less than ten persons on a regular basis do not fall within the definition of factories and are not regulated by the Factories Act. Thus, while the new Employment of Children Act of 1991 may at best help reduce the number of children employed in hazardous occupations in the formal sector, it is unable to do anything about children employed in unregistered establishments in the informal sector where the overwhelming proportion of working children are actually employed.

\section{Working Conditions of Children in Major Occupations}

Since the statistics on child workers reflect mainly the numbers in wage employment, child workers in the agricultural sector do not find an adequate place in quantitative estimates. Yet children working alongside their families in agricultural operations such as seed bed preparations, fodder cutting, rice transplanting, weeding and harvesting may constitute the majority of working children in Pakistan. Such children are increasingly exposed without protective devices to toxic substances in pesticides and fertilizers.' There is now evidence that indiscriminate use of pesticides, many of which are banned in the advanced industrial countries, are responsible for growing health hazards in countries such as Pakistan. For example, during the last decade, 25 percent of pesticides exported to developing countries (including Pakistan) from the U.S. were banned or unregistered in the U.S. Consequently, although developing countries account for only one sixth of the pesticides users, the rate of poisoning there is 13 times as great as in the U.S. ${ }^{6}$

Another dimension of the hazards to which rural child workers are exposed, arises from the production conditions in agriculture: The traditional ties of dependence of poor peasants on landlords in large parts of Punjab and Sindh have been reinforced by cash indebtedness following the "Green Revolution". Children of poor peasant families are often subjected to extra economic coercion. They are in many cases made to work without money wages, as domestic servants in the landlord's manor where they are frequently subjected to humiliation, beating and abuse.

\footnotetext{
${ }^{5}$ See: Akmal Hussain, "Women, Environment and Development". Paper presented to the Centre for Research and Management, Islamabad, February 12, 1991.

${ }^{6}$ Catherine Canfield: "Pesticides Exporting Death", New Scientist, August 16, 1984.

${ }^{7}$ For a detailed analysis of this issue see: Akmal Hussain: "Technical Change and Social Polarization in Rural Punjab", in Strategic Issues in Pakistan's Economic Policy, Progressive Publishers, Lahore, 1988.
} 
In the urban and semi-urban areas, most of the working children are employed in small scale unregistered establishments in the informal sector where the employers can easily evade the legislative protections granted to working children with respect to protection against hazardous occupations and working hours. While the number of children in the large-scale formal sector may have declined, yet even here child work persists to a significant extent by means of the "Contract System". Under this system children remain employees of a contractor in the informal sector while actually working in larger industries, as a device to avoid the law. ${ }^{8}$

Research on child labour in Pakistan is a recent undertaking, and began with a study (Hussain 1986) based on a survey of working children in Lahore in ten occupations where children below age 15 were the predominant element in the work force. 'This study examined the economic and social conditions of working children for the first time in Pakistan. The study showed that children were typically working 54 to 72 hours per week for an average monthly income (cash plus benefits in kind) of Rs. 322. The study also provided evidence on the levels of education of working children, their attitude towards education, frequency of play, their ambitions, their contribution to family income and their wages and benefits by age group and industry. The Hussain (1986) study was followed by the UNICEF (1990) Quetta study ${ }^{10}$ on Child Labour. Unlike the earlier Lahore survey, the Quetta Survey indicated some of the hazards that child workers in various occupations face. It pointed out, for example, that inhalation of wool dust by children exposed them to risk of respiratory diseases, tuberculosis and prolonged work in a squatting posture resulted in leg and spine deformities. Similarly, child workers in steel and iron workshops were exposed to lead poisoning, tetanus, eye diseases while a total of 35 accidents were reported by the study during the year. A more recent study (1990) of 26 small establishments in Lahore showed that all of them employed one or more child under 15 years of age. These work places posed at least one and often several hazards to the health of the child workers, including respiratory diseases such as pneumonia, tuberculosis and silicosis, ophthalmic disorders, mental retardation, damage to various body organs and cancer. ${ }^{11}$

\footnotetext{
8 "Situation Analysis of Children and Women in Pakistan", UNICEF, 1992, Page 84.

9 Akmal Hussain: Economic Growth, Poverty and the Child. Paper presented at the Harvard Conference on Who speaks for the Child, Harvard University, Cambridge, Mass, August 1986. Published in Strategic Issues, op. cit.

${ }^{10}$ UNICEF (1990), Manzooruddin Ahmad; "Child Labour, A Time to Reflect".

${ }^{11}$ Study by Nishtar Medical College, Multan, cited in: "Discover the Working Child", 1990, UNICEF, Islamabad.
} 


\section{Conditions of Working Children in Construction and Related Industries (Secondary Sources).}

There are probably more children working in construction related industries than in construction per se, mainly because work on construction sites (such as carrying bricks, or mixing cement) requires the strength of an adult, or skills (where automatic construction equipment and earth moving equipment is being increasingly used). However, children continue to be employed on building sites and function through an adult contractor in order to avoid the Law. The most important construction related industries where children are employed are brick manufacture (including tiles), cement, steel windows, furnishing (including carpet knotting) and electrification. There is no study so far that examines the question of hazards for working children in the construction and related industries as a whole at the micro level, let alone the national level. However, a few micro level studies some of them based on casual empiricism, others based on small surveys, do exist for individual occupations such as brick kilns and carpet knotting. ${ }^{12}$

UNICEF estimates that at least 250,000 children work on brick kilns. A "guestimate" by the Brick Kiln Owners Federation puts forward a figure of 6,000 brick kilns in Pakistan, with an average of 25 families per site. ${ }^{13}$ These families who live on the sites are locked into a dependency relationship with the owner which is akin to bonded labour. The indebtedness occurs through the Peshgi system under which the labourer borrows from the owner to fulfil his family's consumption requirements. The loan, which the owner readily gives, functions as a trap, because it persists across generations due to high interest charges, manipulation of books, and low wages. During the period of Peshgi repayment (which in many cases is intergenerational) the family are virtual prisoners of the kiln owners and need special permission (not often granted) to leave the premises even for a short period. Physical abuses including rape of women and abduction have been reported. The study on working children in the brick kilns of Sindh notes that the children witness the cruel treatment of their parents by the owners, and grow up in an atmosphere of fear, insecurity and subjugation, which has a long lasting effect on their personality development. Interviews with parents and observation of children provide

\footnotetext{
${ }^{12}$ See for example: Y. Mitha et. al: "Bonded Labour in the Brick Kiln Industry"; S. Rehmatullah and M. Hassan: "Children at Risk, Children Working in Brick Kilns"; UNICEF (1990) / Institute of Social Research and Development: "Children Working on Brick Kilns in Sindh"; S. A. Awan and Abdil Ali Khan: "Child Labour in Carpet Weaving Industry in Punjab".

${ }^{13}$ UNICEF: "Discover the Working Child", op. cit., page 16.
} 
evidence of malnutrition, skin diseases due to contact with clay, dust and exposure to intense heat, as well as respiratory infections. ${ }^{14}$ Another study in NWFP showed that child workers in the brick industry suffered 50 percent more chronic chest infections than their counterparts in neighbouring villages. ${ }^{15}$

A detailed survey based sample study on child workers in the carpet industry in Punjab suggests that over 80 percent of the carpet workers in Punjab are children below age 15 years, including 30 percent under 10 years. ${ }^{16}$ The majority of carpets are knotted at home in carpet weaving villages on a sub-contract basis, while some are made in private centres, factories and a small number in government workshops. 70 percent of the families in the survey sample had taken an advance in return for carpet weaving at home. In most cases the families had failed to pay back the loan within a reasonable time period, and found that they had to continue weaving carpets indefinitely into the future through their children's work.

A majority of the children work more than eight hours a day at the loom with no one working less than six hours. 90 percent of the children earned an average salary of between Rs. 200 to Rs. 500 per month.

The children work in poorly lit and poorly ventilated rooms. All the children surveyed had suffered from fingertip injuries. Other health problems include backache, respiratory diseases and low grade fever indicating chronic infection. 70 percent of the children reported being beaten by parents and employers if they tried to avoid work.

The UNICEF Quetta study mentions hazards faced by working children in a qualitative fashion as one element in its wide ranging discussion. The only survey based study hitherto available which attempts to focus on hazards in industrial sectors/establishments employing children, is a 1990 UNICEF Study titled: Preliminary Study and Survey of Health Hazards and Working Children. Although the focus of the study is not on working children in construction and related industries but on industries in Lahore employing children, yet it is useful in that it attempts to assess the incidence of hazardous activities in the sample industries. The study points out that in the absence of protective devices and adequate ventilation, working children handle and/or breathe toxic substances resulting in a range of health dangers. For example, in paint industries the handling of

14 "Children Working on Brick Kilns in Sindh", Institute of Social Research and Development, Karachi, 1990.

${ }^{15}$ UNICEF: "Discover the Working Child" ... op. cit., page 16.

${ }^{16}$ Saeed A. Awan and Abid Ali Khan: "Child Labour in Carpet Weaving Industry in Punjab". 
chemicals, mixing and dilution of paints, filling, sealing, labeling and storage is done with bare hands and exposed face. Consequently, the children come into frequent skin contact with toxic chemicals such as pigments, dyes, and thinners. Moreover, poor ventilation results in children inhaling toxic fumes from solvents. The disease symptoms resulting from such exposures are coughing, skin dehydration and ophthalmic disorders. Prolonged exposure creates the danger of respiratory diseases, serious ophthalmic disorders, liver, kidney and stomach cancer. In the glass industry, which may be regarded as a construction-related industry (since it also manufactures windowpanes), the child workers are exposed to fine silica sand and high heat from the glass melting furnaces, as well as carbon monoxide. Long exposure to these substances can result in tuberculosis and pneumoconiosis.

In the furniture manufacturing industry the children are exposed to toxic solvents contained in polishing materials. They breathe solvent vapours in poorly ventilated workshops. Prolonged exposure to such chemicals can cause respiratory and ophthalmic diseases as well as persistent brain and body sluggishness.

\section{Child Workers in Construction and Related Industries: Evidence from the Field Survey.}

Methodology

The survey was designed to investigate two inter-related dimensions of child work in the construction and related industries. First, to discover the nature, extent and impact of occupational health and safety risks; second to specify the pattern of child employment across these industries with respect to age groups of children, wage and education level of the child workers, their family status, and the education level of their employers. In the pursuit of these objectives the survey questionnaire was designed so as to enable identification of the specific hazards in each industry, and the number of casualties (injuries and deaths last year) resulting from each type of hazard in each industry. The wage levels, age and education level of the respondents was recorded together with their family status, family income and education level of their employer.

A total of 200 work places or establishments in seven industries were identified for investigation, with the sample size of respondents being 400 (approximately two respondents were interviewed in each workplace). The number of workplaces (and hence number of respondents) assigned to each industry was based on the Quota Sampling Technique. This is a nonprobability equivalent of stratified sampling. This technique was used to 
enable control of non-response bias in the survey. The target population was sub-divided into groups of workplaces/individuals likely to have a homogeneous nature of work related hazards in each sub-group. In the sampling procedure the major strata relevant for the study were identified and then quotas assigned to each stratum according to their approximate proportionate representation in the population. (The latter was based on judgement arrived at after initial field visits which were more extensive than the ones at the interview stage). Accordingly, 58 workplaces (approximately 116 respondents) were specified for the construction industry, 48 workplaces (approximately 96 respondents) in steel window manufacture, 35 workplaces (70 respondents) in the white washing industry, 23 workplaces (46 respondents) in electrification, 17 workplaces $(34$ respondents) in furnishing, 11 workplaces ( 22 respondents) in tiles and eight workplaces (16 respondents) in the cement industry. To bring out the full range of hazards at the workplaces visited and their precise nature, the respondents' information was supplemented by information provided by the interviewers on the basis of personal investigation and visual check of each workplace.

\section{Analysis of Data}

The data shows that there were 16 different kinds of hazards at the workplace with air pollution being by far the hazard most frequently reported by the respondents. See Table 3 . Air pollution includes high levels of carbon monoxide, unburnt carbon particles and silica particles in the air (in tiles manufacture), toxic solvent vapours from paints dyes and thinners, sulphur compounds in varnish solvents used in furniture manufacture, corrosive acid fumes and cyanide in the air, and carcinogenic fumes of vinyl chloride gas.

Table 1 presents the full range of hazards reported, and the percentage of respondents reporting each hazard. This table shows that 30 percent of the respondents report air pollution at workplace followed by dangerous building structure of workplace (reported by 11.1 percent of the respondents), and excessive working hours ( 9 percent). It may be mentioned here that where accidents occur they usually happen near the end of the workday when the child worker has low concentration and poor body coordination due to acute fatigue. So that casualties reported due to hazards such as insufficient light, or proximity of worker to badly insulated electricity wires, may be causally linked with this fatigue factor. Handling toxic chemicals, intensive heat and glare and uncovered manholes in the workplace are also reported by a significant percentage of total respondents interviewed (see Table 1). 
Table-1: Percentage of child workers reporting hazards By type of hazard

\begin{tabular}{|c|c|}
\hline Hazard & Percentage \\
\hline $\begin{array}{l}\text { Health and Safety Hazards resulting from intrusion of } \\
\text { workplace onto the road }{ }^{1}\end{array}$ & 8.2 \\
\hline Dangerous Building Structure $^{2}$ & 11.1 \\
\hline Unsafe Electrical Fittings $^{3}$ & 3.0 \\
\hline Unsafe Use of Equipment ${ }^{4}$ & 3.6 \\
\hline Acute Air Pollution ${ }^{5}$ & 30.1 \\
\hline Handling Toxic Chemicals without protective devices ${ }^{6}$ & 5.0 \\
\hline Using unsafe Steel Cutting Procedure & 0.3 \\
\hline Intense Heat and Glare & 7.7 \\
\hline Danger of Falling into furnaces which lack protective devices & 1.7 \\
\hline Unhygienic Food at Workplace & 8.1 \\
\hline No protection against Welding Sparks & 2.6 \\
\hline Excessive Working Hours $^{7}$ & 9.0 \\
\hline Drain Water spread across Workplace Floor & 2.3 \\
\hline $\begin{array}{l}\text { Uncovered Manhole on premises, cement, dust and/or } \\
\text { Wood Scrap at factory floor where child workers eat food }\end{array}$ & 7.3 \\
\hline
\end{tabular}

Source: Akmal Hussain: Field Survey on Child Workers in Construction and Construction-related Industries, September 1992.

Notes:

1. Includes injuries/deaths caused to child workers by passing vehicles in cases where these workers are employed in open air workshops which intrude onto metalled roads.

2. Includes weak building structure, broken stairs, weak roofs.

3. Includes open switches, electric wires hanging near the workers, naked wires, electric sparks.

4. Includes protruded cutting edges, absence of safety devices on machines.

5. Includes high levels of carbon monoxide, unburnt carbon particles in the air, silica particles in the air (in tiles factories), toxic solvent vapours from paints, dyes and thinners, sulphur compounds in varnish solvents used in furniture manufacture, corrosive acid fumes and cyanide in the air in electroplating units, carcinogenic fumes of vinyl chloride gas (a degraded product of PVC moulding).

6. Toxic dyes, pigments, plasticizers, dryers, acids, mercaptans, acrylic and vinyl resins, used in furniture, paints and plastic moulding units.

7. More than 10 hours of continuous work. 
Table 2 presents the number of casualties reported in each industry due to various hazards. It is important to note that casualties are mainly injuries and respondents reported that individual child workers underwent repeated injuries during a year. The number of workplaces investigated in each industry of course varies across industries due to the sampling procedure [see section on Methodology]. Therefore, column (c) in Table 2 has been constructed to show the propensity of each industry to cause injuries and deaths owing to its particular set of circumstances. It appears that steel window manufacturing industry has the highest number of casualties per workplace (15), followed by construction industry (12) and tiles manufacture (11).

Table-2: Number of casualties last year due to any hazard and number of workplaces, by type of Industry

\begin{tabular}{lccc}
\hline Industry & $\begin{array}{c}\text { (a) } \\
\text { Reported Number* } \\
\text { of Casualties } \\
\text { during last year }\end{array}$ & $\begin{array}{c}\text { (b) } \\
\text { Number of } \\
\text { Workplaces }\end{array}$ & $\begin{array}{c}\text { ( c) } \\
\text { Number of } \\
\text { Casualties per } \\
\text { Workplace last year }\end{array}$ \\
\hline Construction & 677 & 58 & 12 \\
Steel Window & 752 & 48 & 15 \\
Manufacture & & & \\
Electrification & 60 & 23 & 3 \\
Furnishing & 125 & 17 & 7 \\
Tiles & 111 & 11 & 11 \\
Cement & 64 & 8 & 8 \\
White Washing & 160 & 35 & 5 \\
\hline
\end{tabular}

Source: Akmal Hussain: Field Survey on Child Workers in Construction and Construction-related Industries, September 1992.

*Note: Respondents reported that an individual child worker experiences repeated injuries during the year, and returns to work after first aid or medical treatment.

In Table 3 we have attempted to synthesise the data on hazards and resultant casualties in each industry by constructing a standardised Lethality Index for each category of hazards. Similarly, a standardised Danger Index for industries has been constructed to show how dangerous each category of hazards is in terms of its weight in that industry. 
Table-3: Lethality index of hazards and danger index of Industries

\begin{tabular}{|c|c|c|c|c|c|c|c|c|}
\hline \multirow[t]{2}{*}{ Hazard } & \multirow{2}{*}{$\begin{array}{c}\text { (A) } \\
\text { Standardised } \\
\text { Index } \\
\text { of hazards }\end{array}$} & \multicolumn{7}{|c|}{$\begin{array}{c}\text { (B) } \\
\text { Standardized Danger Index of Industry }\end{array}$} \\
\hline & & $\begin{array}{c}\text { Constr- } \\
\text { uction }\end{array}$ & $\begin{array}{c}\text { Steel } \\
\text { Window }\end{array}$ & $\begin{array}{l}\text { Electrifi } \\
\text {-cation }\end{array}$ & $\begin{array}{l}\text { Furnish- } \\
\quad \text { ing }\end{array}$ & Tiles & Cement & $\begin{array}{c}\text { White } \\
\text { Washin } \\
g \\
\end{array}$ \\
\hline $\begin{array}{l}\text { Insufficient Light } \\
\text { at Workplace }\end{array}$ & it & 2.68 & 3.96 & 2.70 & 0.79 & 4.80 & 4.25 & 4.46 \\
\hline $\begin{array}{l}\text { Workplace } \\
\text { hazards due to } \\
\text { incorrect location } \\
\text { of Equipment } \\
\text { and other } \\
\text { Protuberances, } \\
\text { Electricity, } \\
\text { Wires, Switches, } \\
\text { etc. }\end{array}$ & n & 2.65 & 3.74 & - & 1.18 & 2.92 & 3.6 & 2.38 \\
\hline $\begin{array}{l}\text { Lack of } \\
\text { Protective } \\
\text { devices while } \\
\text { using dangerous } \\
\text { Equipment and } \\
\text { Material }\end{array}$ & 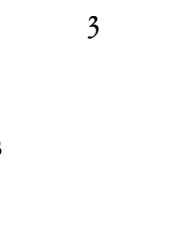 & 2.46 & 2.34 & 1.85 & 2.52 & 2.77 & - & 0.16 \\
\hline $\begin{array}{l}\text { Workplace } \\
\text { dangers due to } \\
\text { Proximity to } \\
\text { Road, etc. }\end{array}$ & 2 & 0.95 & 1.43 & 0.62 & 1 & - & - & 10.54 \\
\hline $\begin{array}{l}\text { Unsafe } \\
\text { Machinery } \\
\text { without Safety } \\
\text { devices }\end{array}$ & 1 & 0.50 & 1.23 & 0.54 & 0.61 & 0.38 & 0.80 & 0.46 \\
\hline $\begin{array}{l}\text { Composite } \\
\text { Danger Index }\end{array}$ & - & 9.24 & 12.7 & 5.71 & 6.1 & 11.33 & 9.05 & 8.00 \\
\hline
\end{tabular}

Source: Akmal Hussain: Field Survey on Child Workers in Construction and Construction-related Industries, September 1992.

The method of constructing the Lethality Index is as follows: The number of casualties was specified for each of five categories of hazards (100 percent of the total casualties were covered by these five categories of hazards). These hazard categories were then ranked in descending order in terms of the number of casualties caused by each. For example, rank number five was assigned to "Insufficient light" which has caused the highest number of casualties (616) and rank number one assigned to "Machinery Without Safety Devices" which has caused the lowest number of casualties (142). 
The standardised Danger Index of industries was constructed as follows: The ratio of respondents reporting a particular hazard category to the total number of respondents in that industry was calculated for each industry. This ratio which signifies the frequency of occurrence of a hazard in that industry was then multiplied by the Lethality Index of that hazard, to get the Danger Index of each hazard category for each industry. A Composite Danger Index (CDI) for each industry is given at the end, which is the sum of the Danger Indices of each hazard for that industry.

Table 3 shows that Steel Windows manufacturing is the most dangerous industry in terms of the work safety risk followed closely by Tiles. Construction and Cement have close third and fourth positions, followed by White Washing, Cement and finally Furnishing. While the Composite Danger Index (CDI) is useful in that it gives the aggregate "Danger Level" of each industry, yet the relative position of the industries with respect to the CDI must be interpreted with caution. The reason is that the danger index is ultimately based on the number of casualties resulting from various hazards in various workplaces in that industry in one particular year. Now many of the hazards such as handling of toxic chemicals protective devices, or breathing carbon monoxide and silica dust, may impact the physiology of the child worker over a period of time; similarly, hazards such as weak building structure, machines without safety devices may not have actually caused accidents in the particular year being reported, but may do so in the future. Thus, if the same workplaces were investigated a few years into the future, (assuming no improvement in working conditions) then the relative number of casualties owing to various hazards across industries may well be different, and hence the ranking of industries with respect to CDI may change. What is important to note is that there is a significant variation in the number of casualties resulting from various hazard categories. Therefore, the degree to which the composition of hazards present in a particular industry is weighted towards the more lethal hazards would make that industry potentially dangerous.

No significant association was observed between workplace casualties and education level of the employer. However, in the case of three hazards, (inadequate light, proximity to road and dangerous building), the extent of the hazard is much less frequent in cases where the employer has a college education compared to cases where the employer has only school education. (See Table 4). 
Table-4: Number of child workers reporting casualties* Due to selected hazards by education level of employer

\begin{tabular}{|c|c|c|c|c|c|c|c|}
\hline Hazards & All Levels & Illiterate & Primary & Middle & Matric & F.A. & B.A. \\
\hline $\begin{array}{l}\text { Inadequate light at } \\
\text { workplace }\end{array}$ & 173 & 1 & 37 & 37 & 79 & 17 & 2 \\
\hline Proximity to Road & 16 & 0 & 0 & 3 & 8 & 3 & 2 \\
\hline $\begin{array}{l}\text { Dangerous Building } \\
\text { Structure }\end{array}$ & 18 & 0 & 4 & 4 & 9 & 1 & 0 \\
\hline
\end{tabular}

Source: Akmal Hussain: Field Survey on Child Workers in Construction and Construction-related Industries, September 1992.

- Casualties occurred in last year. The numbers refer not to the number of casualties, but the number of respondents in each case reporting one or more casualties.

Table 5 presents the percentage of child workers reporting sex abuse in each industry and in each age group. In the case of tiles, cement, furnishing and construction, between 11 percent to 15 percent of the respondents (in the respective industries) report sex abuse against their person. In the case of electrification, steel windows and white washing the prevalence of sex abuse is at a lower level, ranging from 2 to 4 per cent.

Table-5: Sex abuse at work place

Number of children reporting sex abuse against them as a percentage of respondents in the industry

By age and type of industry

\begin{tabular}{lccc}
\hline \multicolumn{1}{c}{ Industry } & $\begin{array}{c}\text { All Age Groups } \\
\text { Percentage }\end{array}$ & $\begin{array}{c}\text { Age Group 8-10 } \\
\text { Percentage }\end{array}$ & $\begin{array}{c}\text { Age Group 11-15 } \\
\text { Percentage }\end{array}$ \\
\hline Construction & 15 & 6 & 9 \\
Steel Windows & 4 & 2 & 2 \\
Electrification & 2 & - & 2 \\
Furnishing & 15 & 6 & 9 \\
Tiles & 11 & 5 & 6 \\
Cement & 13 & - & 13 \\
White Washing & 4 & 1 & 3 \\
\hline
\end{tabular}

Source: Akmal Hussain: Field Survey on Child Workers in Construction and Construction-related Industries, September 1992. 
Employer violence like sex abuse is prevalent to a significant extent although it varies (as in the case of sex abuse) considerably between industries. As Table 6 shows the average prevalence of employer violence against respondents is five per cent for industries with the percentage figure being much higher at 15 per cent in furnishing, low in white washing at one percent. The reason could be that the market for furniture is highly quality conscious, so employers in an attempt to force children to achieve perfection in varnishing and smoothening the wood may be beating them excessively. In the case of white washing, however, the task being much simpler and variation in quality due to worker negligence much lower, employers may not find it necessary to "discipline" their workers. There seems to be no distinction between age with respect to employer violence, with the percentage figure (five per cent) being the same for both age groups.

Table-6: Employer Violence

Number of child workers reporting employer violence against them By industry and age of child

\begin{tabular}{|c|c|c|c|c|c|c|c|c|c|c|c|}
\hline \multicolumn{9}{|c|}{ Employer Violence against Child Workers by Industry } & \multicolumn{3}{|c|}{$\begin{array}{c}\text { Employer } \\
\text { Violence by Age } \\
\text { of Child Worker }\end{array}$} \\
\hline $\begin{array}{c}\text { All } \\
\text { Indus- } \\
\text { tries }\end{array}$ & $\begin{array}{l}\text { Construc- } \\
\text { tion and } \\
\text { Wood } \\
\text { Work }\end{array}$ & $\begin{array}{c}\text { Steel } \\
\text { Windows }\end{array}$ & $\begin{array}{c}\text { Electrif } \\
\text { cation }\end{array}$ & $\begin{array}{l}\text { Furni- } \\
\text { shing }\end{array}$ & Tiles & Cement & $\begin{array}{l}\text { White } \\
\text { Washing }\end{array}$ & Others & $\begin{array}{c}\text { All } \\
\text { Ages }\end{array}$ & $8-10$ & D11-15 \\
\hline 20 & 7 & 7 & 1.3 & 5 & 0 & 0 & 1 & 0 & 20 & 7 & 13 \\
\hline (5) & (4) & (7) & (4) & (15) & $(0)$ & (0) & (1) & (0) & (5) & (5) & (5) \\
\hline
\end{tabular}

Source: Akmal Hussain: Field Survey on Child Workers in Construction and Construction-related Industries, September 1992.

Note: 1. Figures in brackets refer to the number of child workers reporting employer violence against them as a percentage of the total number of respondents in that category.

2. Violence including punching with fist or use of sticks, chains.

As Table 7 shows by far the largest proportion of child workers have a wage of Rs. 200 per month or less with the pattern being broadly consistent across industries and age groups. However, the exceptions are the electrification industry steel windows and tiles industries where a substantial proportion of child workers fall in the higher wage category of Rs. 401 to Rs. 600. This may be because electrification requires higher skill levels and 
tiles and steel windows manufacture is far more hazardous than other industries. This is borne out by the composite danger index of 11.33 and 12.7 in the case of the latter two industries respectively. (See Table 3).

Table-7: Number of child workers in various wage categories By age and type of industry

\begin{tabular}{|c|c|c|c|c|c|c|c|c|}
\hline \multirow[t]{2}{*}{ Industry } & \multicolumn{4}{|c|}{$\begin{array}{l}\text { Number of Child Workers } \\
\text { in Age Group } 8-10\end{array}$} & \multicolumn{4}{|c|}{$\begin{array}{l}\text { Number of Child Workers } \\
\text { in Age Group } 11-15\end{array}$} \\
\hline & $\begin{array}{c}\text { Rupees } \\
\text { Per } \\
\text { month } \\
\text { upto } 200\end{array}$ & $\begin{array}{c}\text { Rupees } \\
\text { Per } \\
\text { month } \\
201-400\end{array}$ & $\begin{array}{c}\text { Rupees } \\
\text { Per } \\
\text { month } \\
401-600\end{array}$ & $\begin{array}{c}\text { Rupees } \\
\text { Per } \\
\text { month } \\
601 \& \\
\text { above }\end{array}$ & $\begin{array}{c}\text { Rupees } \\
\text { Per } \\
\text { month } \\
\text { upto } \\
200 \\
\end{array}$ & $\begin{array}{c}\text { Rupees } \\
\text { Per } \\
\text { month } \\
201-400\end{array}$ & $\begin{array}{c}\text { Rupees } \\
\text { Per } \\
\text { month } \\
401-600\end{array}$ & $\begin{array}{c}\text { Rupees } \\
\text { Per } \\
\text { month } \\
601 \& \\
\text { above }\end{array}$ \\
\hline $\begin{array}{l}\text { Construc- } \\
\text { tion }\end{array}$ & 20 & 13 & 2 & 8 & 40 & 20 & 2 & 11 \\
\hline $\begin{array}{l}\text { Steel } \\
\text { Windows }\end{array}$ & 16 & 7 & 4 & 1 & 22 & 13 & 24 & 9 \\
\hline $\begin{array}{l}\text { Electrifi- } \\
\text { cation }\end{array}$ & 3 & 3 & 1 & 2 & 15 & 10 & 9 & 3 \\
\hline Furnishing & 10 & 3 & - & - & 11 & 6 & 2 & 2 \\
\hline Tiles & 4 & 2 & - & 1 & 5 & 4 & 6 & 2 \\
\hline Cement & 2 & 1 & - & - & 10 & 1 & 1 & 1 \\
\hline $\begin{array}{l}\text { White } \\
\text { Washing }\end{array}$ & 26 & 2 & - & 1 & 35 & 2 & 1 & 2 \\
\hline
\end{tabular}

Source: Akmal Hussain: Field Survey on Child Workers in Construction and Construction-related Industries, September 1992.

Table 8 compares wage income of the child workers with their family income, by industry. In the case of all industries it turns out that child worker's income constitutes a very substantial proportion of family income. The figure varies between 27 percent for tiles to 50 percent for cement. The proportion of child worker income to family income may be higher in this study when compared to an earlier (1986) micro study which covered a much broader range of occupations. ${ }^{17}$ The reason (apart from the fact that current monthly wages have increased over the last six years) is that construction and construction related industries are far more hazardous than other occupations in which children are employed (e.g., roadside hotels, sweepers, etc) and parents are quite aware of this fact. So that parents who

\footnotetext{
${ }^{17}$ See Akmal Hussain: Economic Growth, Poverty and the Child, op. cit.
} 
send their children to work in the Construction and related industries may be under much greater pressure of poverty, which explains the higher child wage/family income ratios.

Table-8: Comparison of child workers' income with family income

\begin{tabular}{lccc}
\hline \multicolumn{1}{c}{ Industry } & $\begin{array}{c}\text { Average Wage (Cash) } \\
\text { of Child Worker } \\
\text { (a) }\end{array}$ & $\begin{array}{c}\text { Average Income } \\
\text { of Family(Monthly) }\end{array}$ & Percentage \\
(b) & (a/b) \\
\hline Construction & 799 & 1661 & $42 \%$ \\
Steel Windows & 493 & 1755 & $28 \%$ \\
Electrification & 697 & 1860 & $37 \%$ \\
Furnishing & 388 & 1378 & $28 \%$ \\
Tiles & 481 & 1740 & $27 \%$ \\
Cement & 799 & 1580 & $50 \%$ \\
White Washing & 604 & 1720 & $35 \%$ \\
\hline
\end{tabular}

Source: Akmal Hussain: Field Survey on Child Workers in Construction and Construction-related Industries, September 1992.

As Table 10 shows, an overwhelming majority of child workers in our survey were living with both parents. (This is consistent with the findings of the UNICEF Quetta Survey). This is true for all industries except cement where 50 percent of the respondents were living with a friend or relative. It is significant that between six percent to 12 percent of child workers in various industries were living alone. Table 9 shows that the average wage of child workers living alone is higher than for those who live with one or both parents.

Table-9: Monthly wage of child workers by family status of child worker

\begin{tabular}{lc}
\hline \multicolumn{1}{c}{ Family Status } & Average Wage (Monthly) Rupees \\
\hline Living alone & 795 \\
With both Parents & 555 \\
With one Parent & 461 \\
Other (Friend/Relative) & 606 \\
\hline
\end{tabular}

Source: Akmal Hussain: Field Survey on Child Workers in Construction and Construction-related Industries, September 1992. 
Table-10: Family status of child workers by type of industry

\begin{tabular}{lccccc}
\hline \multicolumn{1}{c}{ Industry } & $\begin{array}{c}\text { Any } \\
\text { Status }\end{array}$ & $\begin{array}{c}\text { Living } \\
\text { with both } \\
\text { Parents }\end{array}$ & $\begin{array}{c}\text { Living } \\
\text { with one } \\
\text { Parents }\end{array}$ & $\begin{array}{c}\text { Living with } \\
\text { Friend/ } \\
\text { Relative }\end{array}$ & $\begin{array}{c}\text { Living } \\
\text { Alone }\end{array}$ \\
\hline Construction & 100 & 91.0 & 1.4 & 1.4 & 6.2 \\
Steel Windows & 100 & 85.4 & 7.9 & 4.5 & 6.2 \\
Electrification & 100 & 94.0 & - & 4.0 & 12.0 \\
Furnishing & 100 & 86.4 & 4.5 & 4.5 & 4.5 \\
Tiles & 100 & 76.9 & 3.8 & 19.3 & - \\
Cement & 100 & 50.0 & - & 50.0 & - \\
White Washing & 100 & 66.7 & 8.3 & 16.7 & 8.3 \\
\hline
\end{tabular}

Source: Akmal Hussain: Field Survey on Child Workers in Construction and Construction-related Industries, September 1992.

\section{Implications of Survey Data for Policy and Action}

The data indicates that child workers in the construction and related industries are facing at least 16 different hazards to their health and safety with approximately 12 casualties per work place during the last year. Steel Windows manufacture; Tiles and Construction industries are the most dangerous in terms of risk to health and safety of the child workers. Insufficient light at workplace, badly insulated wires, lack of protective devices for workers using dangerous equipment and materials and poor ventilation are amongst the most lethal hazards in the industries we have surveyed. Clearly, the long term task can be none other than withdrawing these working children from occupations which cause repeated injuries, chronic diseases, physical and mental deformities and in some cases even death. However, the experience of Pakistan and other South Asian countries is that mere legislation is not enough to protect these children. (After all there has been a law against employment of children in precisely such occupations since 1938 and a much more rigorous law since 1991). Action is simultaneously needed on three fronts:

1. An administrative mechanism targeted towards the ending of child labour in hazardous occupations over the next five years needs to be urgently put in place. This mechanism can consist of specifying the number of children, location of hazardous work units, the details of the hazards in each work unit and the names of the employers in the area under the 
jurisdiction of each Assistant Commissioner in the country. This data should be available to the Commissioner of each division whose task should be to indicate specific achievement targets for the Assistant Commissioners, (in terms of which their salaries, promotion and benefits should be decided). The achievement targets would consist of the following: (a) Closing down by a target date work units whose location, equipment and production processes are so hazardous as to be beyond redemption. In this case, alternative source of livelihood for the employees would have to be organised with a credit facility to enable the establishment of alternative enterprises by the employers.

(b) Replacing child workers with adults in cases where the workplace can be rendered safe without drastic intervention. Alternative livelihood for the children in non-hazardous occupations together with provision of education should be organised.

(c) To design proposals for the reduction or elimination of hazards at the workplace through the introduction of protective devices for workers, safety and automatic shutdown devices on machines, improving the ventilation of the workplace, improved lighting of the workplace, and insulation of the wiring system of building and strengthening the building structure. The technical support and credit required to achieve this objective should also be organised by the Assistant Commissioners with support from relevant government agencies.

2. Perhaps the most efficacious way of alleviating the condition of child workers in hazardous industries and ultimately withdrawing them from these dangerous occupations, is intervention at the local mohalla level through community organisation. Save the Children Organisations (SCO's) involving the participation of the local community need to be established by means of trained catalysers developed by district level support organisations called District Child Support Centres (DCSC's). The community organisation would have the task of negotiating with the employers to improve workplace safety to replace children working in hazardous occupations with adults, to provide the children withdrawn from such work with education, alternative skills and part time employment opportunities. The task of the DCSC's would be to provide trained cadres to mobilise and organise local communities, provide technical support regarding improvement of workplace safety, organise credit to enable the workplace owners to install new equipment, acquire protective devices, use safer chemicals where substitutes are available and improve the electrical wiring and building structure. Finally, the DCSC's need to be coordinated by an apex organisation such as the Trust for Voluntary Organisations which has recently been established in Islamabad 
or alternatively a new National Urban Support Programme along the lines of the National Rural Support Programme (NRSP) instituted earlier this year.

3. A pilot programme for employers in construction and related industries should be initiated in each of the major cities of Pakistan. The purpose of the pilot programme would be to form an employees association for units in the informal sector backed by technical and credit support from the Ministry of Industries. The technical and credit support should be designed to make employers aware of the health and accident risks to the employees, and to develop programmes to achieve work safety at the workplace, to improve technology and replace children with adult workers with special monetary incentives for employers who achieve this objective within a specified time limit. 
Akmal Hussain 79

\section{References}

Awan, S. A. and Abdil Ali Khan, 1992. Child Labour in Carpet Weaving Industry in Punjab.

Canfield, Catherine, 1984. "Pesticides Exporting Death", New Scientist, August 16, 1984.

Hussain, Akmal, 1986. "Economic Growth, Poverty and the Child". Paper presented at the Harvard Conference on Who Speaks for the Child, Harvard University, Cambridge, Mass, August 1986. Published in Strategic Issues in Pakistan's Economic Policy, Progressive Publishers, Lahore, 1988.

Hussain, Akmal, 1988. Technical Change and Social Polarization in Rural Punjab, in Strategic Issues in Pakistan's Economic Policy, Progressive Publishers, Lahore.

Hussain, Akmal, 1991. "Women, Environment and Development". Paper presented to the Centre for Research and Management, Islamabad, February 12, 1991.

ISRD, 1990. Institute of Social Research and Development: "Children Working on Brick Kilns in Sindh".

Mitha, Y, et. a1, 1989. "Bonded Labour in the Brick Kiln Industry", Human Rights Commission of Pakistan.

Planning Commission, Government of Pakistan: "National Programme of Action for the Goals for Children and Development in the 1990's", (Not dated).

Rehmatullah S., and Hassan, M., 1989. "Children at Risk.”

UNICEF, 1992. (Punjab Programme Office): Preliminary Study and Survey on Health Hazards and Working Children.

UNICEF, 1992. "Situation Analysis of Children and Women in Pakistan".

UNICEF, 1990. Islamabad: "Discover the Working Child".

UNICEF, 1990. "Child Labour, A Time to Reflect", by Manzooruddin Ahmad. 